\title{
The Trend in Distribution of Q223R Mutation of Leptin Receptor Gene in Amoebic Liver Abscess Patients from North India: A Prospective Study
}

\author{
Anil Kumar Verma, ${ }^{1}$ Vineet Ahuja, ${ }^{2}$ and Jaishree Paul ${ }^{1}$ \\ ${ }^{1}$ School of Life Sciences, Jawaharlal Nehru University, New Delhi 110067, India \\ ${ }^{2}$ Department of Gastroenterology, All India Institute of Medical Sciences, New Delhi 110052, India \\ Correspondence should be addressed to Jaishree Paul; jpaul33@hotmail.com
}

Received 26 February 2014; Accepted 6 May 2014; Published 9 July 2014

Academic Editor: Abhay R. Satoskar

Copyright (C) 2014 Anil Kumar Verma et al. This is an open access article distributed under the Creative Commons Attribution License, which permits unrestricted use, distribution, and reproduction in any medium, provided the original work is properly cited.

\begin{abstract}
Host genetic susceptibility is an important risk factor in infectious diseases. We explored the distribution of Q223R mutation in leptin receptor gene of amoebic liver abscess (ALA) patients of North India. A total of 55 ALA samples along with 102 controls were subjected to PCR-RFLP analysis. The frequency of allele "G" (coding for arginine) was in general high in Indian population irrespective of the disease. Our results of Fisher exact test shows that heterozygous mutant (QQ versus QR, $P=0.049$ ) and homozygous mutant (QQ versus $\mathrm{RR}, P=0.004$ ) were significantly associated with amoebic liver abscess when compared with homozygous wild (QQ).
\end{abstract}

\section{Introduction}

The protozoan parasite Entamoeba histolytica is estimated to cause 100 million infections and 100,000 deaths worldwide annually and malnutrition is known to increase susceptibility to infection [1]. Amebiasis is more common in malnourished children, a state that afflicts approximately one-third of children in the developing world [2]. The most common manifestation of E. histolytica infection in India is either diarrhea with ulcerative lesion in caecum and colon (intestinal amebiasis) or amoebic liver abscess (ALA). Invasive trophozoites gain access to liver via hepatic portal vein and cause amoebic liver abscess due to necrotic lysis of the liver tissue. It varies in size and number. Necrotic lesions may be single or multiple and may occur in left or right lobe of liver. The common symptoms of ALA are fever, pain in the right hypochondrium, and liver tenderness $[3,4]$. Recently a point mutation (Q223R, rs1137101, A to G) in leptin receptor gene at 223aa position has been found to be associated with the susceptibility to E. histolytica infection and disease outcome in Bangladesh [5]. It was observed that the children with allele for arginine (223R) were almost 4 times more susceptible to infection compared to those homozygous for the ancestral glutamine allele (223Q). In terms of nucleotides, Q (glutamine) is encoded by A (adenine) whereas $R$ (arginine) is encoded by G (guanine). Leptin is a hormone/cytokine produced largely by adipocytes and to some extent by the stomach, skeleton muscles, and placenta [6]. Leptin plays several important roles in human physiology. It acts through the leptin receptor (LEP-R), a singletransmembrane-domain receptor of the cytokine receptor family which connects nutrition and immunity. In addition to regulating neuroendocrine function, energy homeostasis, haematopoiesis, and angiogenesis, leptin is an important modulator of both the innate and adaptive immune systems [7]. It has been earlier stated that malnutrition in children aggravates the propensity of amoebiasis [8]. Therefore, we proposed to study the segregation of alleles A and G of LEPR gene responsible for Q223R mutation in North Indian population and if it has any association with ALA.

\section{Methodology}

2.1. Biological Samples. The study patients were recruited from the Department of Gastroenterology, All India Institute 
of Medical Sciences, New Delhi, India, after necessary ethical clearances were obtained for the study. All the participating patients gave written consent for the study. ALA pus samples were collected from patients by the attending physician and necessary precautions were taken during pus aspiration from liver, so as to avoid any contamination. The pus aspiration from liver was carried out in those patients who did not respond to chemotherapy and where aspiration was unavoidable for case management. The demographic and clinical details of the patients are represented in Table 1 . The samples were transported at $4^{\circ} \mathrm{C}$ within two hours after collection and stored at $-20^{\circ} \mathrm{C}$ until processed. Blood samples from 102 individuals without any enteric or liver disease were included in the study as controls. The blood samples were collected by venipuncture in vacutainer tubes (BD NJ, USA) containing anticoagulant $\mathrm{K}_{2}$ EDTA solution from individuals visiting the hospital.

2.2. DNA Extraction from Whole Blood and ALA Pus. DNA from blood samples was extractedusing standard protocol [9]. Briefly blood (stored in ACD or EDTA) was resuspended in $15 \mathrm{~mL}$ polypropylene centrifugation tubes with $3 \mathrm{~mL}$ of nuclei lysis buffer $(10 \mathrm{mM}$ Tris- $\mathrm{HCl}, 400 \mathrm{mM} \mathrm{NaCl}$, and $2 \mathrm{mM} \mathrm{Na}{ }_{2}$ EDTA, $\mathrm{pH}$ 8.2). The cell lysates were digested overnight at $37^{\circ} \mathrm{C}$ with $0.2 \mathrm{~mL}$ of $10 \%$ SDS and $0.5 \mathrm{~mL}$ of a proteinase $\mathrm{K}$ solution ( $1 \mathrm{mg}$ proteinase $\mathrm{K}$ in $1 \%$ SDS and $2 \mathrm{mM} \mathrm{Na} \mathrm{NaDTA}_{2}$. After digestion was complete, $1 \mathrm{~mL}$ of saturated $\mathrm{NaCl}$ (approximately $6 \mathrm{M}$ ) was added to each tube and shaken vigorously for 15 seconds, followed by centrifugation at $2500 \mathrm{rpm}$ for 15 minutes. The precipitated protein pellet was left at the bottom of the tube and the supernatant containing the DNA was transferred to another $15 \mathrm{~mL}$ polypropylene tube. Exactly 2 volumes of absolute ethanol were added and the tubes were inverted gently several times until the DNA precipitated. The precipitated DNA strands were removed with a plastic spatula or pipette and transferred to a $1.5 \mathrm{~mL}$ microcentrifuge tube containing 100$200 \mathrm{pl} \mathrm{TE}$ buffer $\left(10 \mathrm{mM}\right.$ Tris- $\mathrm{HCl}$ and $0.2 \mathrm{mM} \mathrm{Na}_{2}$ EDTA, $\mathrm{pH}$ 7.5). The DNA was allowed to dissolve for 2 hours at $37^{\circ} \mathrm{C}$ before quantification. Genomic DNA from liver abscess pus samples for PCR was isolated using QIAamp DNA stool kit using manufacturer guidelines.

2.3. Primer Designing. E. histolytica specific primers were designed after Srivastava et al. from SINE2 [10]. EhSINE2 is highly abundant non-LTR, nonautonomous retrotransposon in E. histolytica genome [11]. Some of SINE2 copies show internal deletion, due to which the amplicon revealed size variation and multiple bands were observed near $350 \mathrm{bp}$. The nucleotide sequence of primer is as follows: $F 5^{\prime}$-GTCAGAGACACCACATGAA- $3^{\prime}$ and R $5^{\prime}$-CGAGACCCCTTAAAGAAACCC $-3^{\prime}$ [10]. A set of PCR primers was designed to amplify the fragment of leptin receptor gene spanning the exon 6 locus of the gene carrying Q223R mutation. Primer sequences are $\mathrm{F} 5^{\prime}$-CCTGCTTTAAAAGCCTATCCAG$3^{\prime}$ and $\mathrm{R} 5^{\prime}$-AGTGTTAAGCAAAGTGAGATAAGC-3'. Primers sequences were bioinformatically analysed to ensure specificity using BLAST Programme of NCBI [12].
TABLE 1: Demographic and clinical details of amoebic liver abscess patients $(n=55)$.

\begin{tabular}{lc}
\hline (1) Sex: $n$ male (\%)/female (\%) & $48(87.2) / 7(12.7)$ \\
(2) Age at diagnosis: mean (SD) & $43(13.9)$ \\
15-30: $n(\%)$ & $9(16.12)$ \\
31-above: $n(\%)$ & $46(83.87)$ \\
(3) Duration of disease (range) & $7-20$ days \\
(4) Alcoholic: $n$ (\%) & \\
Yes & $36(65.45)$ \\
No & $16(29.0)$ \\
Ex & $3(5.45)$ \\
(5) Location of abscess: $n(\%)$ & \\
Right lobe of liver & $51(92.70)$ \\
Left lobe of liver & $4(7.3)$ \\
(6) No. of abscesses & $41 / 14(75 / 25)$ \\
(single/multiple): $n(\%)$ & \\
(7) Whether first aspiration & $55 / 0(100 / 0)$ \\
(yes/no): $n$ (\%) & Metronidazole and \\
(8) Drugs for treatment & ciprofloxacin \\
(9) Ethnicity & Aryan \\
(10) Location & North India \\
\hline
\end{tabular}

2.4. PCR-RFLP. A total of 55 ALA samples along with 102 controls were subjected to PCR-RFLP analysis. DNA was amplified using leptin receptor specific primers. PCR was performed in a touch gene (Nugen Scientific, USA) machine. Thin walled $0.2 \mathrm{~mL}$ tubes were used for amplification. A typical PCR reaction $(20 \mu \mathrm{L})$ included $7.8 \mu \mathrm{L}$ of autoclaved milliQ water, $2 \mu \mathrm{L}$ of $10 \mathrm{X}$ PCR buffer with $\mathrm{MgCl}_{2}$ (containing $750 \mathrm{mM}$ Tris- $\mathrm{HCl}\left(\mathrm{pH} 8.8\right.$ at $\left.25^{\circ} \mathrm{C}\right), 200 \mathrm{mM}\left(\mathrm{NH}_{4}\right)_{2} \mathrm{SO}_{4}, 0.1 \%$ Tween-20, $1.5 \mathrm{mM} \mathrm{MgCl}$ ), $2 \mu \mathrm{L}$ of dNTP mix (containing $2 \mathrm{mM}$ of each dNTP), $2 \mu \mathrm{L}(20 \mathrm{pmol})$ of each primer forward as well as reverse, and $0.2 \mu \mathrm{L}$ of TaqDNA polymerase $(5 \mathrm{U} / \mu \mathrm{L}$, MBI Fermentas, USA) and $2.0 \mu \mathrm{L}$ of template DNA. The amplification conditions were one cycle of $94^{\circ} \mathrm{C}$ for $5 \mathrm{~min}$ followed by 30 cycles of $94^{\circ} \mathrm{C}$ for $30 \mathrm{~s}$, annealing $55^{\circ} \mathrm{C}$ for $1 \mathrm{~min}$, extension at $72^{\circ} \mathrm{C}$ for $30 \mathrm{sec}$, and finally one cycle of $72^{\circ} \mathrm{C}$ for $10 \mathrm{~min}$ and finally held at to $4^{\circ} \mathrm{C}$. Volume of template DNA used $(2.0 \mu \mathrm{L} ; \sim 50 \mathrm{ng})$ worked fine for PCR amplification. The sample containing all reagents except the template DNA was treated as the negative control. The size and integrity of the products were checked by electrophoresis. $10 \mu \mathrm{L}$ of the PCR product was run on a $0.8-1.2 \%$ agarose gel at $5 \mathrm{~V} / \mathrm{cm}$ for an appropriate time period. Restriction enzyme BseNI was used to digest the PCR amplified product of $386 \mathrm{bp}$ and the fragments generated upon digestion are represented in Figure 1. Restriction enzyme BseNI digests only when the sequence reads nucleotide $A$ at the locus. Thus digestion of 386 bp PCR product yielded three bands of $221+146+19 b p$ in case of homozygous (AA, assuming A as wild allele) wild and two bands of $367+19 \mathrm{bp}$ in case of homozygous mutant (GG) (Figure 1). As expected, the digestion of heterozygous mutant yielded four bands of $367+221+146+19$ bp as shown in a representative gel. All bands except $19 \mathrm{bp}$ were visible on 


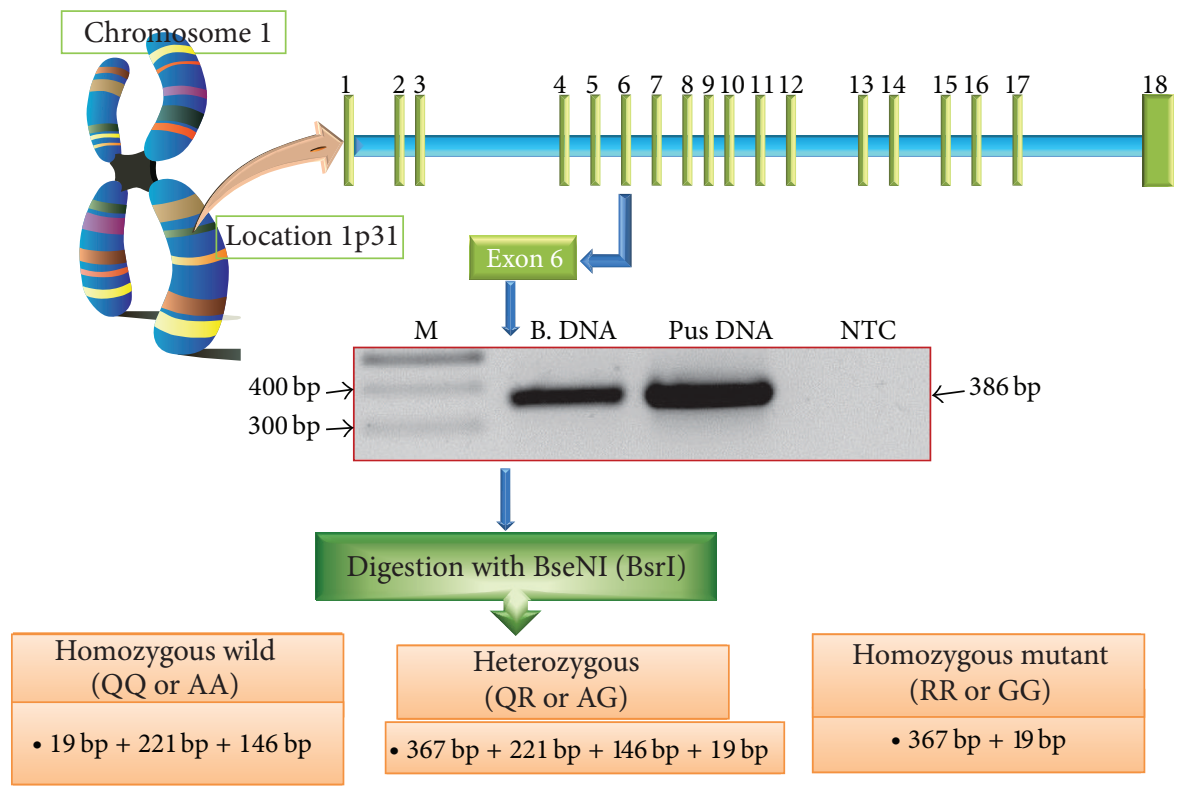

FIGURE 1: Schematic representation of the methodology followed for detection of Q223R mutation in leptin receptor gene. Digestion of PCR amplified product of $386 \mathrm{bp}$ by restriction enzyme BseNI (BsrI) yields three bands of $221 \mathrm{bp}+146 \mathrm{bp}+19 \mathrm{bp}$ in homozygous wild, four bands of $367 b p+221 b p+146 b p+19 b p$ in heterozygous, and two bands of $367 b p+19 b p$ in homozygous mutant. Allele "A" codes for glutamine and allele " $G$ " codes for arginine in leptin receptor gene. Lane $\mathrm{M}=100 \mathrm{bp}$ Marker, lane B. DNA = human blood genomic DNA, lane pus DNA = ALA (amoebic liver abscess) pus DNA, and NTC = no template control.

$1.5 \%$ agarose gel. Sequencing of mutated fragment confirmed the presence of mutation in Indian population (Figures 2(a) and $2(\mathrm{~b}))$.

2.5. Statistical Analysis. Data was evaluated by SPSS software version 12 using standard contingency $\chi^{2}$ tests or Fisher's exact test for calculating the differences in genotype frequency between cases and controls. A two-tailed $P$ value $<0.05$ was considered significant. Multiple comparisons were done using one way ANOVA based on the conservative Bonferroni correction. The significance level of $\alpha=0.05$ was chosen for all sets.

\section{Results and Discussion}

Out of 55 collected samples, 54 samples gave positive result with PCR conducted with E. histolytica specific primers accounting for $98 \%$ efficiency in diagnosis. We assessed the association of the SNP with a number of different diseases related outcomes and for possible confounding variables. Genotype and allele frequencies for SNP rs1137101 (Q223R) in LEPR gene of ALA cases were stratified by phenotypic subgroups and represented in Table 2. Genotype and phenotype profiling of ALA patients studied here revealed that gender, age, and alcoholism are other important risk factors for amoebic liver abscess. Frequency of allele $\mathrm{G}$ was calculated and is represented in Figure 3(a). We did not observe significant difference in allele frequency of " $G$ " among control and ALA patients. However, the distribution of genotype frequency followed the following pattern AA $<$ GG $<A G$ in control and $\mathrm{GG}<\mathrm{AA}<\mathrm{AG}$ in ALA patients of North
TABLE 2: Genotype and allele frequencies for SNP rs1137101 (Q223R) in $L E P R$ gene of ALA cases stratified by phenotypic subgroups $(n=$ $55)$.

\begin{tabular}{lcccc}
\hline SNP & \multicolumn{4}{c}{ SNP rs1137101 (Q223R) in $L E P R$ gene } \\
Genotype & AA (15) & AG (31) & GG (9) & Total (55) \\
\hline (1) Sex & & & & \\
$\quad$ Male & 10 & 30 & 8 & 48 \\
$\quad$ Female & 5 & 1 & 1 & 7 \\
(2) Age at diagnosis (Yr) & & & & \\
15-30 & 5 & 4 & 0 & 9 \\
31-above & 10 & 27 & 9 & 46 \\
(3) Alcoholic & & & & \\
$\quad$ Yes & 11 & 19 & 6 & 36 \\
No & 4 & 10 & 2 & 16 \\
$\quad$ Ex & 0 & 2 & 1 & 3 \\
(4) No. of abscesses & & & & \\
$\quad$ Single & 8 & 27 & 6 & 41 \\
$\quad$ Multiple & 7 & 4 & 3 & 14 \\
\hline
\end{tabular}

India (Figure 3(b)). Fisher exact test was performed to check the association of mutation Q223R with ALA using SPSS version 12 software. Our results showed that heterozygous mutant (QQ versus $Q R, P=0.049$ ) and homozygous mutant (QQ versus $\mathrm{RR}, P=0.004$ ) were significantly associated with amoebic liver abscess when compared with homozygous wild (QQ) (Table 3). Mutation Q223R in leptin receptor gene is very important as it increases the susceptibility of $E$. histolytica infection in malnourished children. Malnutrition represents a significant health problem in the developing 


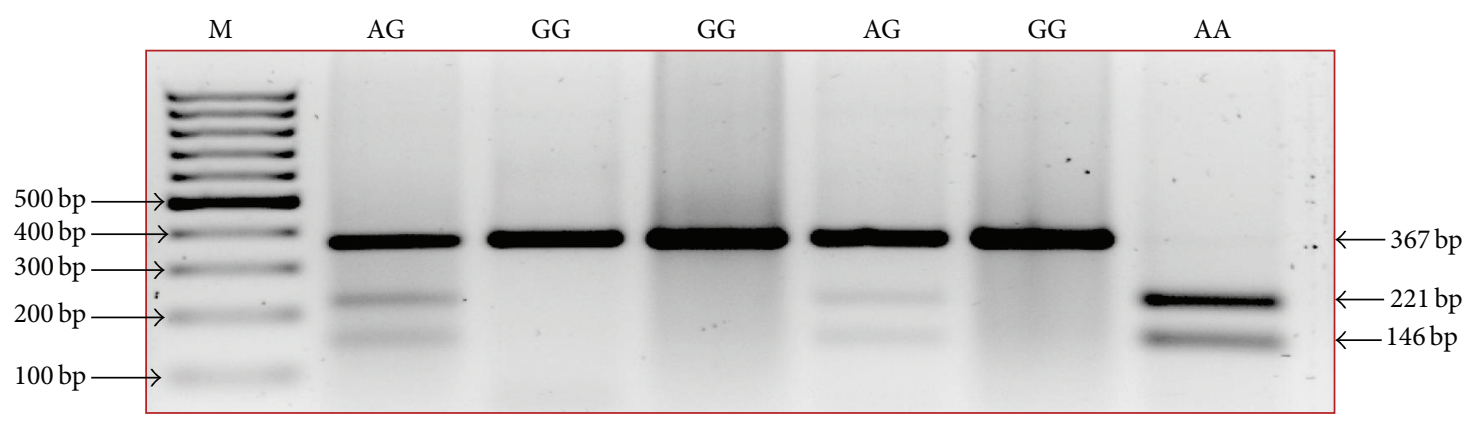

(a)
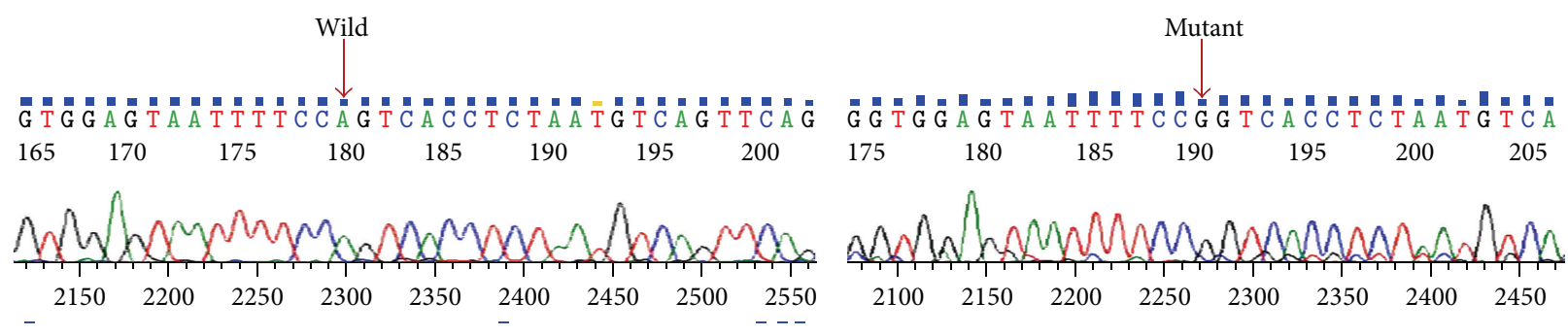

(b)

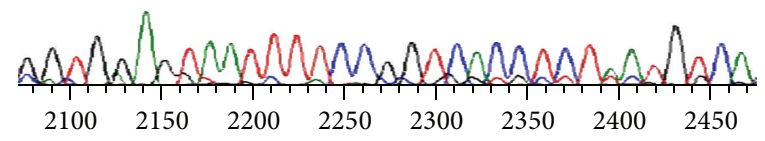

Figure 2: (a) PCR-RFLP analysis of Q223R SNP (rs1137101) from leptin receptor gene. Lane M = 100 bp Marker, lane AG, lane GG, and lane AA represent restriction enzyme digested PCR product of ALA pus DNA of different genotypes. After digestion with BseNI restriction enzyme, wild type AA is visible as two bands $221 \mathrm{bp}, 146 \mathrm{bp}$ and the third band of $19 \mathrm{bp}$ is invisible due to smaller size. Heterozygous AG is visible as three bands $367 \mathrm{bp}, 221 \mathrm{bp}, 146 \mathrm{bp}$ and $19 \mathrm{bp}$ (invisible) whereas homozygous mutant GG is visible as bands of $221 \mathrm{bp}, 146 \mathrm{bp}$ and $19 \mathrm{bp}$ (invisible). (b) Sequencing results of wild "A" and mutant "G" are detected by PCR-RFLP confirming the presence of SNP in DNA of ALA patients.

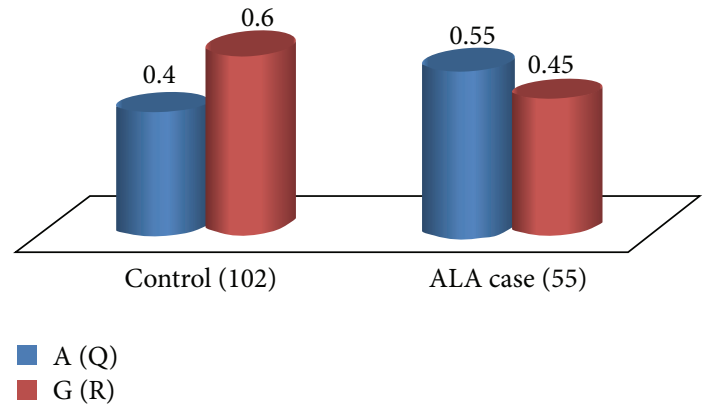

(a) Allele frequency for RS1137101 (Q223R)

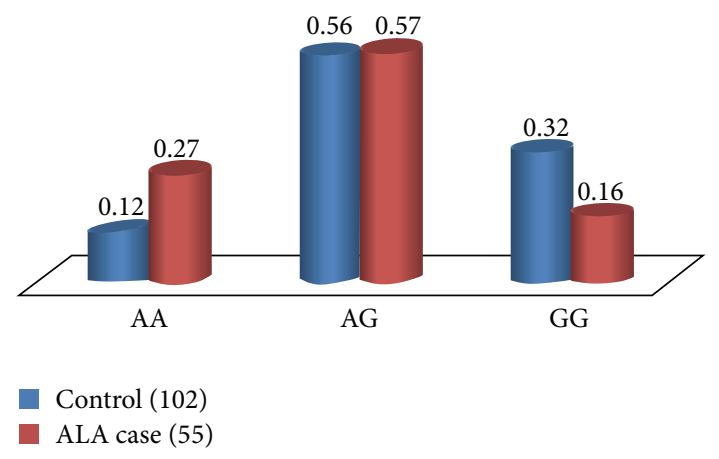

(b) Genotype frequency of RS1137101 (Q223R) in LEPR gene

FIGURE 3: Allele and genotype frequencies of SNP Q223R (rs1137101) in LEPR gene in amoebic liver abscess patients and control samples of North India. (a) Distribution of allele frequency. Allele "A" codes for glutamine whereas allele "G" codes for arginine amino acid in $L E P R$. (b) Distribution of genotype frequency.

world including India and growing body of evidence has indicated an epidemiological connection between susceptibility to infection and malnutrition. The leptin levels in malnourished children have been reported to be lower than the well-nourished ones with a concomitant suppression of inflammatory responses $[13,14]$. Two recent studies had explored the link between malnutrition, leptin signaling, and susceptibility to amebic infection. The first study by Duggal et al. involved the prospective observation of a cohort of 185 Bangladeshi children by household visits every other day over a period of nine years. During this study period,
90 percent of the children enrolled had at least one bout of E. histolytica infection. The children were also tested for polymorphisms in their leptin and leptin receptor genes. They found that mutation Q223R increased susceptibility to intestinal infection by E. histolytica depending on the presence of allele " $G$ " in homozygous or heterozygous state $[5]$.

The second study by Guo et al. showed that mice lacking the functional leptin receptor developed devastating mucosal destruction after E. histolytica infection [15]. Leptinmediated resistance to amebiasis is via its action on intestinal 
TABLE 3: Association of leptin receptor gene (LEPR) polymorphism at Q223R locus with amoebic liver abscess. ALA case $(n=55)$, Control $(n=102), \mathrm{Q}$ (glutamine $)=\mathrm{A}$ (wild), and $\mathrm{R}$ (arginine $)=$ $\mathrm{G}$ (mutant). $P$ value $=$ or $<0.05$ was considered significant. ${ }^{*}$ Refers to significant $P$ values.

\begin{tabular}{lcccc}
\hline rsl137101 & $N=$ ALA (control) & OR & $95 \%$ CI & $P$ value \\
\hline QQ versus QR & $15(12): 31(57)$ & 0.435 & $0.181-1.045$ & $0.049^{*}$ \\
QQ versus RR & $15(12): 9(33)$ & 0.218 & $0.076-0.629$ & $0.004^{*}$ \\
QR versus RR & $31(57): 9(33)$ & 0.501 & $0.213-1.182$ & 0.08 \\
\hline
\end{tabular}

epithelium rather than hematopoietic cells or the brain and requires leptin receptor signaling through STAT3 [15]. The in vitro studies have shown that the Q223R polymorphism in leptin receptor attenuates leptin-dependent STAT3 activation to that of the wild-type (WT) receptor and it is the leptin regulation of host apoptotic genes TRIB1 and suppressor of cytokine signaling 3 (SOCS3) via STAT3 which is responsible for protection [16]. A recent study in E. histolytica infected mice (223R mice compared to Q223 mice) has shown that the majority of leptin-linked differentially regulated genes were involved in apoptosis, cellular proliferation, or recruitment of hematopoietic cells. The differential regulation of these genes suggests that the Q223R polymorphism attenuates the ability of LEPR stimulation to protect cells against amebic killing and/or apoptosis [17]. Similarly our study also shows that most of the ALA patients had "AG" genotype and allele "G" is associated with ALA patients. The presence of allele " $G$ " is an important risk factor in Indian population.

\section{Conclusion}

Our study concludes that the mutation Q223R is associated with susceptibility to E. histolytica infection in North Indian population but large population based studies are needed to confirm our observation in Indian population. The frequency of allele " $G$ " is higher in Indian population than that of allele "A." The worldwide distribution of allele "G" in Q223R mutation shows that it is more prevalent in Asian and African subcontinents whereas allele " $\mathrm{A}$ " is more predominant in European population.

\section{Conflict of Interests}

The authors declare that there is no conflict of interests regarding the publication of this paper.

\section{Acknowledgments}

This study was supported by a research grant to Jaishree Paul from the Department of Biotechnology, Government of India. Anil Kumar Verma is grateful to the Indian Council of Medical Research, New Delhi, India, for research fellowship. The authors gratefully acknowledge the subjects who participated in this study.

\section{References}

[1] H. P. Verkerke, W. A. Petri Jr., and C. S. Marie, "The dynamic interdependence of amebiasis, innate immunity, and undernutrition," Seminars in Immunopathology, vol. 34, no. 6, pp. 771785, 2012.

[2] S. N. Moonah, N. M. Jiang, and W. A. Petri Jr., "Host immune response to intestinal amebiasis," PLoS Pathogens, vol. 9, no. 8, Article ID e1003489, 2013.

[3] J. Santi-Rocca, M. Rigothier, and N. Guillén, "Host-microbe interactions and defense mechanisms in the development of amoebic liver abscesses," Clinical Microbiology Reviews, vol. 22, no. 1, pp. 65-75, 2009.

[4] N. Sharma, A. Sharma, S. Varma, A. Lal, and V. Singh, "Amoebic liver abscess in the medical emergency of a North Indian hospital," BMC Research Notes, vol. 3, article 21, 2010.

[5] P. Duggal, X. Guo, R. Haque et al., "A mutation in the leptin receptor is associated with Entamoeba histolytica infection in children," Journal of Clinical Investigation, vol. 121, no. 3, pp. 1191-1198, 2011.

[6] J. M. Friedman and J. L. Halaas, "Leptin and the regulation of body weight in mammals," Nature, vol. 395, no. 6704, pp. 763770, 1998.

[7] N. M. Mackey-Lawrence and W. A. Petri Jr., "Leptin and mucosal immunity," Mucosal Immunology, vol. 5, no. 5, pp. 472479, 2012.

[8] D. Mondal, R. Haque, R. B. Sack, B. D. Kirkpatrick, and W. A. Petri, "Attribution of malnutrition to cause-specific diarrheal illness: Evidence from a prospective study of preschool children in Mirpur, Dhaka, Bangladesh," American Journal of Tropical Medicine and Hygiene, vol. 80, no. 5, pp. 824-826, 2009.

[9] S. A. Miller, D. D. Dykes, and H. F. Polesky, "A simple salting out procedure for extracting DNA from human nucleated cells," Nucleic Acids Research, vol. 16, no. 3, p. 1215, 1988.

[10] S. Srivastava, S. Bhattacharya, and J. Paul, "Species- and strainspecific probes derived from repetitive DNA for distinguishing entamoeba histolytica and entamoeba dispar," Experimental Parasitology, vol. 110, no. 3, pp. 303-308, 2005.

[11] A. A. Bakre, K. Rawal, R. Ramaswamy, A. Bhattacharya, and S. Bhattacharya, "The LINEs and SINEs of Entamoeba histolytica: comparative analysis and genomic distribution," Experimental Parasitology, vol. 110, no. 3, pp. 207-213, 2005.

[12] S. F. Altschul, W. Gish, W. Miller, E. W. Myers, and D. J. Lipman, "Basic local alignment search tool," Journal of Molecular Biology, vol. 215, no. 3, pp. 403-410, 1990.

[13] S. E. Moore, G. Morgan, A. C. Collinson, J. A. Swain, M. A. O'Connell, and A. M. Prentice, "Leptin, malnutrition, and immune response in rural Gambian children," Archives of Disease in Childhood, vol. 87, no. 3, pp. 192-197, 2002.

[14] U. E. Schaible and S. H. E. Kaufmann, "Malnutrition and infection: Complex mechanisms and global impacts," PLoS Medicine, vol. 4, no. 5, article el15, 2007.

[15] X. Guo, M. R. Roberts, S. M. Becker et al., "Leptin signaling in intestinal epithelium mediates resistance to enteric infection by Entamoeba histolytica," Mucosal Immunology, vol. 4, no. 3, pp. 294-303, 2011.

[16] C. S. Marie, H. P. Verkerke, S. N. Paul, A. J. Mackey, and W. A. Petri, "Leptin protects host cells from Entamoeba histolytica 
cytotoxicity by a STAT3-dependent mechanism," Infection and Immunity, vol. 80, no. 5, pp. 1934-1943, 2012.

[17] N. M. Mackey-Lawrence, X. Guo, D. E. Sturdevant et al., "Effect of the leptin receptor Q223R polymorphism on the host transcriptome following infection with Entamoeba histolytica," Infection and Immunity, vol. 81, no. 5, pp. 1460-1470, 2013. 

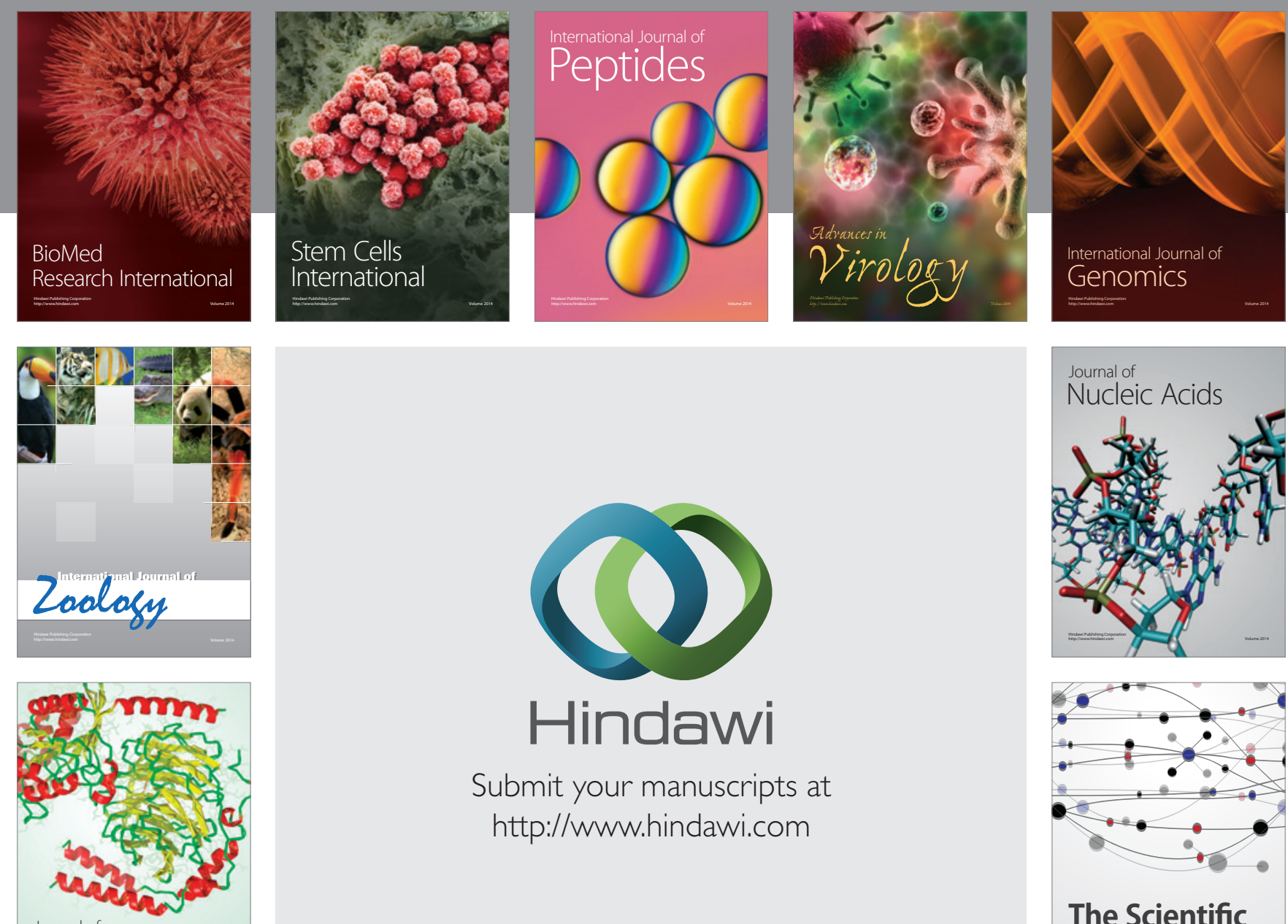

Submit your manuscripts at

http://www.hindawi.com

Journal of
Signal Transduction
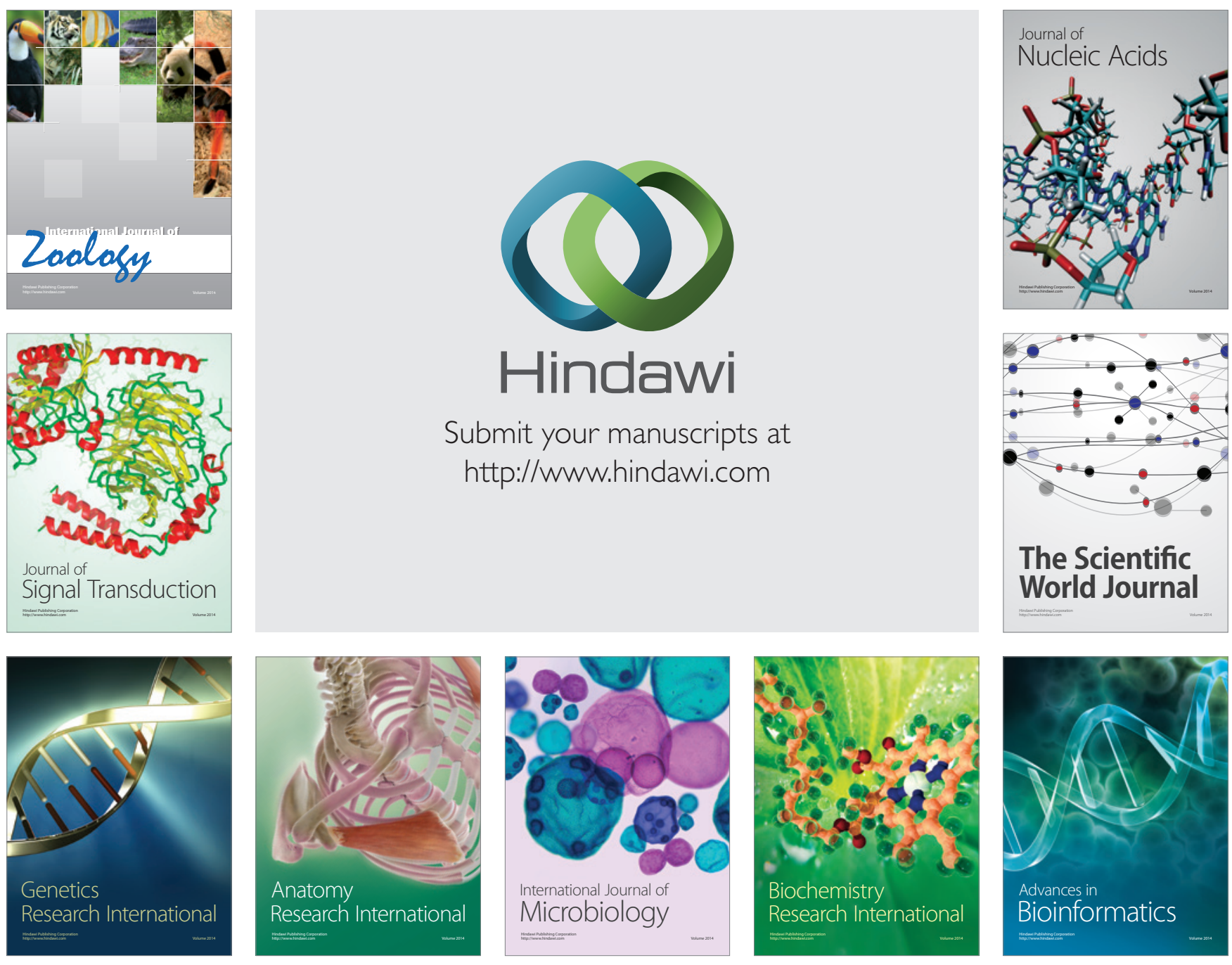

The Scientific World Journal
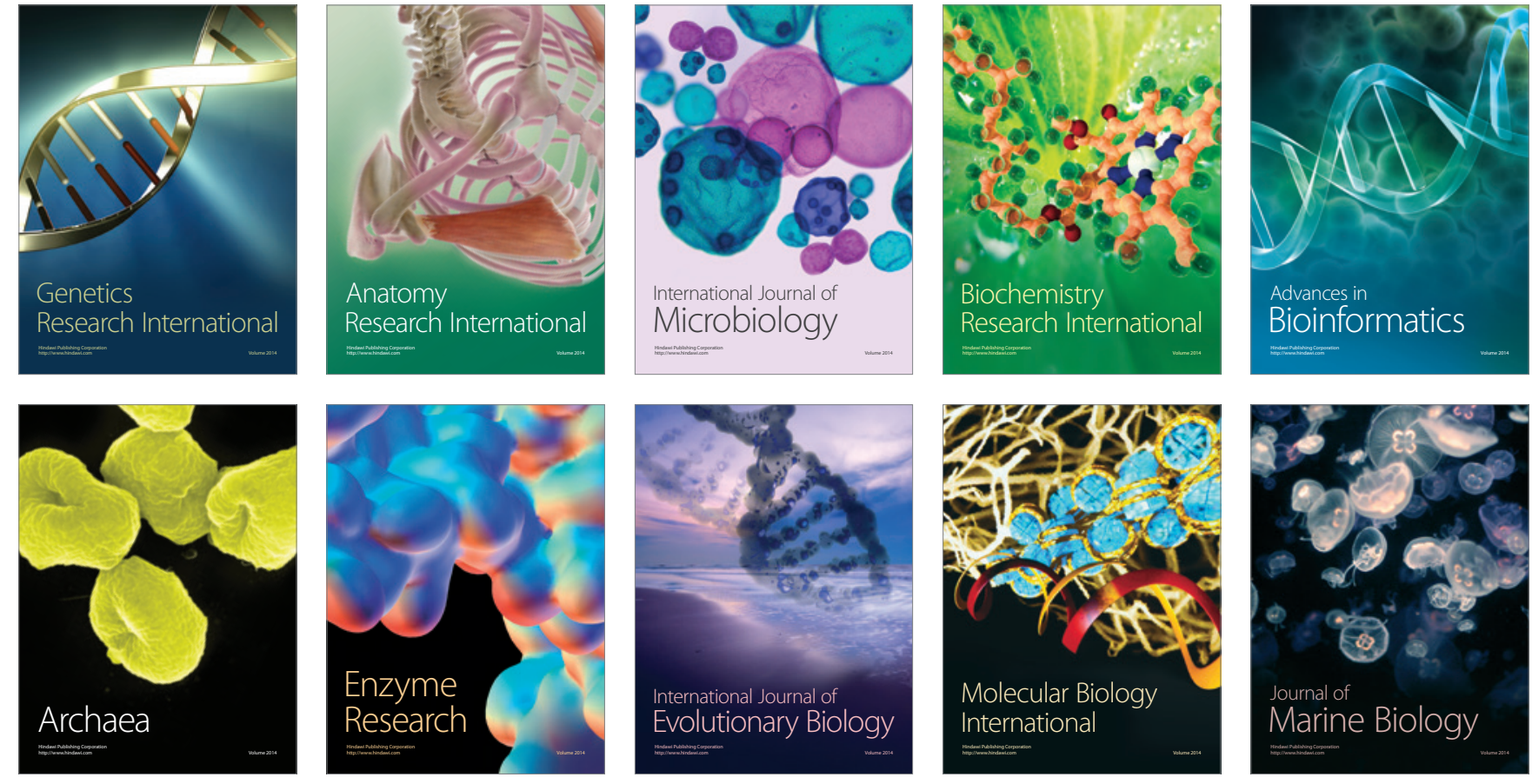